\title{
Smutek jest nasz, bydto jest ich Funkcja zaświadczająca w muzyce ludowej i zaangażowanej na przykładzie nueva canción
}

\author{
The sorrows are ours, \\ the cattle are someone else's \\ Testimonial function in folk and engaged \\ music - the case of nueva canción
}

\begin{abstract}
DOI: 10.12775/LL.1.2021.005 | CC BY-ND 3.0 PL
ABSTRACT: From the anthropological perspective the main functions of music can be described as communicative, emotional, integrative and aesthetic. Additionally music has numerous other functions such as: informative, reviving, creative, stimulating, motivating, contestative, condemning and testimonial. In music of nueva cancion movement in Latin America in the 6os and the 70 s the testimonial function is of particular importance - the same function is also typical of folk music, and used to express social commitment. The same is true of the music created by the American folk revival movement. The aim of the article is to show that the use of the testimonial function is an element that connects folk music with various types of engaged music.
\end{abstract}

KEYWORDS: folk music, nueva canción, politics, folk revival, testimonial function

\section{Wstęp}

Muzyka to zjawisko natury estetycznej i historycznej, aktywnie przekształcające się, a jednocześnie, poprzez uwikłanie zarówno w różnorodne nurty kulturowe, jak i w wydarzenia polityczne, mające intensywny wpływ na życie społeczne i polityczne 
świata. Muzyka bywa bazą refleksji ideologicznej, jak również praktycznym narzędziem działań społecznych, a nawet czynnikiem interpretowanym jako sprawczy wobec zmian historycznych ${ }^{1}$. Wszystkie te zadania może spełniać w ramach swych różnorodnych funkcji. W literaturze przedmiotu istnieje duża odmienność w opisie owych funkcji i sposobie ich hierarchizowania. Iwona Massaka wskazuje na funkcję komunikacyjną, emocjonalną, integracyjną, a także rekreacyjną i estetyczną (Massaka 2003: 23). Z kolei Alan Merriam, twórca antropologii muzyki, wymienia ich w sumie aż dwanaście, czyli: rekreacyjną, estetyczną, komunikacyjną, symboliczną, ludyczną, integrującą, wyrażania ekspresji emocjonalnej, wzmacniania kondycji fizycznej, egzekwowania norm społecznych, uprawomocniania, stabilizowania i podtrzymywania kultury, a za Charlesem Keilem dodaje też funkcje katarktyczną i solidaryzującą (Merriam 1964: 223-226). Te same funkcje posiada także muzyka ludowa, traktowana $\mathrm{w}$ tym artykule jako nieustannie ewoluujący system komunikacji wykorzystywany jako swoiste narzędzie do celów społecznych i politycznych (Massaka 2009: 322), cechujące się wielkim potencjałem ekspresyjnym i uczuciowym. Dzięki temu potencjałowi muzyka ludowa może pełnić dodatkowo inne funkcje, które Pablo Vila (2014: 3-4) określa jako uświadamiającą (czyli informującą o pewnych zjawiskach natury społeczno-kulturowej), rewitalizującą (czyli odradzającą pewne wątki czy kulturę grupy), kreacyjną (służącą budowie pewnej rzeczywistości, czego przykładem mogą być hymny i marsze tworzone na potrzeby rewolucji francuskiej), aktywizującą (czyli motywującą do wykonywania wyznaczonych działań; dobrym przykładem są piosenki powstające w dobie wczesnego socjalizmu w naszym kraju), kontestującą (czyli podważającą i krytykująca zastaną sytuację) oraz zaświadczającą. Istota tej ostatniej polega na tym, że w formie przekazu muzycznego pewne sytuacje historyczne i egzystencjalne ukazywane są jako zjawiska o cechach uniwersalnych i charakterystycznych dla bytu ludzkiego w ogóle. Wymienione funkcje opisane zostały w różnym stopniu w literaturze naukowej. Celem niniejszego artykułu jest analiza funkcji kreacyjnej i zaświadczającej ujawniających się współcześnie w obszarze budowania tożsamości narodowej w nurcie muzyki nueva canción.

Nurt ten, którego korzenie sięgają lat 6o. i 70. XX w., zainicjowany został w Chile, a następnie rozprzestrzenił się w innych krajach Ameryki Łacińskiej. Zrodził się w środowiskach muzyków o poglądach lewicowych, wspierających Salvadora Allende - pierwszego socjalistycznego prezydenta na tym kontynencie. W Chile należeli doń m.in. Violeta Parra (uznawana za założycielkę ruchu), Patricio Manns, Víctor Jara, Rolando Alarcón, Payo Grondona, Patricio Castillo, Homero Caro, Tito Fernández oraz liczne zespoły muzyczne. W 1973 r. po przewrocie wojskowym pod wodzą generała Augusto Pinocheta, który zawrócił Chile z drogi reform charakterystycznych dla ustroju socjalistycznego (m.in. reforma rolna, wprowadzenie systemu powszechnej edukacji i praw pracowniczych, poprawa sytuacji bytowej najuboższych), muzycy nurtu nueva canción byli prześladowani i zmuszani do emigracji. Jednak nadal pełnili swe funkcje społeczne, wykonując repertuar zaangażowany i antyreżimowy, stworzony $\mathrm{w}$ oparciu o muzykę ludową tego regionu. W swoich

1 Jak podaje Danuta Gwizdalanka (1999: 147), wroga wobec muzyki dodekafonicznej opinia publiczna oskarżała jej twórcę, Arnolda Schonberga i jego naśladowców o awanturnictwo polityczne i stwarzanie zagrożenia dla porządku społecznego monarchii habsburskiej, a nawet o doprowadzenie do jej upadku. 
utworach wykorzystywali oni folklor, jednocześnie przekształcając go w sposób świadomy i celowy, według zasad, które opiszę w dalszej części artykułu.

\section{Funkcja kreacyjna muzyki ludowej}

Funkcja kreacyjna muzyki odnosi się do wszystkich jej oddziaływań, które mają stworzyć pewną rzeczywistość społeczną. W odniesieniu do budowania zbiorowych tożsamości zagadnienie to posiada bogatą literaturę, najlepiej opracowaną w kontekście historycznych zmagań o kształt wspólnot narodowych w Europie. W XIX w., w okresie kształtowania się koncepcji nowożytnych narodów, twórcy tak zwanej kultury wysokiej często sięgali do poszczególnych tradycji etnicznych. Nazwanie tych tradycji ludowymi było jednym z zabiegów w procesie budowania narodowych mitologii, a tym samym konstruowania poczucia ciągłości kulturowej oraz kreowania grupowej solidarności i związku z określonym terytorium (Smith 1989: 29-32). Lud według ówczesnego przekonania miał być skarbcem pradawnej, niezmąconej obcymi naleciałościami tożsamości lokalnej. Takie założenia towarzyszyły włączaniu poezji i muzyki ludowej do kanonu sztuki narodowej. Emblematycznym przykładem tej strategii w kulturze polskiej jest twórczość Adama Mickiewicza i Fryderyka Chopina. Opisany proces, zgodny z kanonem epoki romantyzmu, miał miejsce w wielu krajach Europy w XIX w. Ostatnim bodaj działaniem w tym duchu była praca Béli Bartóka i Zoltána Kodály’a na terenie Węgier w początkach XX w. Obaj kompozytorzy od 1905 r. zajmowali się zbieraniem folkloru muzycznego na węgierskiej wsi oraz komponowali inspirowane nim utwory artystyczne. Muzyka nurtu nueva canción pełniła tę samą funkcję kreacyjną w Ameryce Łacińskiej, co dowodzi, że pomimo uzyskania przez państwa tego kontynentu suwerenności w XIX w., niełatwy proces kształtowania się ich narodowości był w drugiej połowie XX w. nadal w toku. Nie była to zresztą sytuacja wyjątkowa, gdyż zakończenie budowania struktur państwowych częstokroć stawało się dopiero impulsem wzbudzającym aspiracje do kształtowania kultury narodowej, także w innych częściach świata. W procesie tym funkcja kreacyjna muzyki w sposób płynny łączyła się z funkcją integracyjną, czyli tą, która jednoczy grupy ludzkie, także całe narody, wokół pewnych idei.

\section{Tożsamość modyfikowana folklorem - przykład Chile ${ }^{2}$}

Anthony Smith wyróżnia dwie metody budowania kanonu kultury narodowej: poprzez biurokratyczną inkorporację wybranych uprzednio treści oraz poprzez wysiłek elit intelektualnych danego kraju (Smith 1989: 52-70). Ten drugi przypadek odpowiada sytuacji w Ameryce Łacińskiej z okresu aktywności ruchu nueva canción. Ruch ten, znany pod różnymi nazwami ${ }^{3}$, u swego podłoża miał na celu odnalezienie tożsamości oraz korzeni kulturowych kontynentu. Uczestniczący w nim pieśniarze w poszukiwaniu bliskiego ich lewicowej ideologii materiału ludowego stawali się etnografami - badaczami terenowymi. Patrząc na ich działania w kontekście teorii Smitha, można powiedzieć, że dokonywali oni najpierw kodyfikacji twórczości

\footnotetext{
2 Ten podrozdział jest skróconą wersją mojego artykułu Zdobycze komunizmu. O rewolucyjnych pieśniarzach Ameryki Łacińskiej (Laskowska-Otwinowska 2019).

3 Np. nuevo cancionero w Argentynie lub nueva trova na Kubie.
} 
ludowej poprzez jej zapisanie, a następnie jej kanonizacji ${ }^{4}$ według kryteriów estetycznych, intelektualnych i politycznych, które zostaną scharakteryzowane poniżej. Proces włączania nowych elementów do zasobów tradycji opisuje również stworzony przez Petera Bergera i Thomasa Luckmana schemat obejmujący następujące etapy: opracowywanie wybranych treści przez autorytety, poddanie tych treści dyskusji społecznej, następnie ich rytualizację w celu utrwalenia w pamięci zbiorowej, i wreszcie po ich społecznej weryfikacji ostateczne zaliczenie do kanonu tradycji (Berger, Luckman 1983: 96-97). Wszystkie elementy tego schematu odnajdziemy w pracy pieśniarzy ruchu nueva canción: zbieranie materiału folklorystycznego, jego opracowanie (przetworzenie), prezentacja i poddanie weryfikacji społecznej poprzez wielokrotne odtwarzanie (dodajmy, że to odtwarzanie następowało często w warunkach kryzysów społeczno-politycznych, co mogło przyspieszyć symbolizację treści) oraz włączenie do kanonu tekstów kultury narodowej. Cały ten proces można odtworzyć w przypadku utworu chilijskiego zespołu Quilapayun, pt. Cantata Popular Santa Maria de Iquique, co zostanie zaprezentowane w dalszej części artykułu.

W przypadku elit intelektualnych Ameryki Łacińskiej w latach 60. i 7o. XX w. kryterium politycznym budowy kanonu pieśni narodowych na bazie folkloru stała się ideologia socjalistyczna i komunistyczna, przy czym wykorzystywano tu też retorykę niepodległościową pieśni z okresu walki o suwerenność poszczególnych państw. Stworzeniem i umocnieniem owego kanonu zajęli się pieśniarze, a jego propagowanie miało służyć mobilizacji podmiotów społecznych (funkcja integracyjna) wokół trwałego, ideowego fundamentu kulturowego, którym była więź ze wspólnotą wyobrażoną własnego narodu (Anderson 1997). Materiałem źródłowym dla twórczości opisywanego ruchu była przede wszystkim indiańska muzyka regionu Andów, folklor kreolski, a w niektórych miejscach również muzyka afrykańska przyniesiona na grunt Ameryki Łacińskiej wraz z niewolnictwem. Folklor, jako część kultury ludowej, wzbudzał duże zainteresowanie lewicującej inteligencji. Poparcie ze strony popularnych wówczas w całej Ameryce Łacińskiej ruchów i partii lewicowych wpływało na prace pieśniarzy-etnografów na kilka sposobów, m.in. poprzez postulat łączenia idei postępu społecznego i cywilizacyjnego z troską o ludność indiańską, jako najbardziej upośledzoną warstwę ludową. Jak zauważył Tadeusz Łepkowski (1987: 95), „[s]prawa indiańska została utożsamiona ze sprawa chłopską, spleciona nierozerwalnie $\mathrm{z}$ kwestią wyzwolenia społecznego i tworzeniem nowego narodu [...]”. Lewicowy program meksykańskiego prezydenta Lázaro Cárdenasa ${ }^{5}$, stanowiący pewien wzór dla całego kontynentu, stawiał znak równości pomiędzy Indianami i proletariatem, wspominając o potrzebie emancypacji: „lecz zawsze w oparciu o jego tożsamość rasową, z szacunkiem uznając zarówno jego świadomość, jak i osobowość" (Łepkowski 1987: 98). Jak pisałam w jednym z wcześniejszych tekstów, „łączenie dwóch idei: równości społecznej oraz samorealizacji kulturalnej poprzez odnowienie kontinuum kulturowego ludów tubylczych było wspólnym mianownikiem problemów dekolonizacyjnych całego ówczesnego świata” (Laskowska-Otwinowska 2019: 515). nie, umocnienie i utrwalenie albo formalne zamrożenie (fixivity) w tekście pisanym” (Halili 2012: 215). 
Wykorzystanie pieśni do mobilizacji mas zgodne było też z sugestiami i wskazówkami Antonia Gramsciego, słynnego i popularnego wówczas w środowiskach lewicowych włoskiego historyka, dziennikarza, filozofa marksistowskiego i współzałożyciela Komunistycznej Partii Włoch. Gramsci nie tylko badał zależności między wykorzystaniem muzyki w edukacji a radykalizacją proletariatu, ale też wskazywał na nieocenioną w tym względzie rolę folkloru. Pisał on, że „[f]olklor nie powinien być traktowany jako malownicze dziedzictwo, ale jako rzecz bardzo poważna, do której należy poważnie podchodzić” (Gramsci 1961: 261). Myśl Gramsciego była stosowana w krajach socjalistycznych w różnym stopniu i w różny sposób. Jej praktyczna realizacja w Polsce w postaci organizowania państwowych zespołów pieśni i tańca, takich jak „Śląsk” czy „Mazowsze”, różniła się bardzo od działań ruchu nueva canción. Repertuar polskich zespołów, który uzyskał akceptację społeczną a zarazem stał się wizytówką Polski za granicą, miał głównie wymiar stylizacji estetycznych, podczas gdy utwory pieśniarzy z Ameryki Łacińskiej należały do muzyki walczącej - najpierw o realizację idei socjalistycznych, później również z reżimem Antonio Pinocheta (Vila 2014: 2-4).

Podejście Gramsciego ugruntowało się w krajach tego kontynentu również dlatego, że pasowało do roli intelektualistów jako pragmatyków działających blisko ludu, którą warstwie wykształconej wyznaczył wpływowy meksykański filozof, Alfonso Reyes (1889-1959). Jego znaczenie dla Ameryki Łacińskiej jest nie do przecenienia, gdyż rozważając problematykę tożsamości całego kontynentu, wypracował on podstawy podejścia do odrębności narodowej i kontynentalnej, głosząc historyczne i kulturowe braterstwo krajów Ameryki Łacińskiej6. Podstawowym założeniem jego koncepcji była akceptacja różnorodności etnicznej Ameryki Południowej połączona z ideami uniwersalizmu człowieczeństwa i powszechnego obywatelstwa. W swych rozważaniach ukuł on pojęcie „naszoamerykańskości” (hiszp. nuestroamericano), które oznaczało wspólnotę tożsamości i kultury Ameryki Łacińskiej, ideę rozwijaną do dziśs. Koncepcja ta wpłynęła na sposób prowadzenia badań folklorystycznych przez przedstawicieli nueva canción, którzy nie ograniczali się w nich do własnego kraju, lecz studiowali folklor krajów ościennych i komponowali utwory muzyczne o charakterze wieloetnicznym, w organiczny sposób łącząc problematykę lokalnych i panlatynoamerykańskich oddziaływań.

Obok twórczości ludowej do obszaru zainteresowań muzycznych nurtu nueva canción należała też wyjątkowa i specyficzna muzyka religijna okresu chrystianizacji ludów tubylczych znana pod nazwą baroku misyjnego. Muzyka ta rozwijała się w okresie misji jezuickich, kiedy wykorzystywanie wrażliwości muzycznej rdzennych ludów odgrywało istotną rolę ewangelizacyjną. Zakonnicy, zauważywszy szczególnie silne zainteresowanie tubylców muzyką, zamieniali części mówione mszy na śpiewane i grane, przy czym do wykonawstwa zapraszali samych Indian, grających na własnych instrumentach. Indianie zostawali ministrantami i nauczycie-

6 Idee integracji kontynentu w odniesieniu do jego jedności cywilizacyjnej głosili w okresie walki o niepodległość niektórzy jej bojownicy, m.in. Simon Bolivar czy Jose de San Martin.

7 Głosi ją np. filozof argentyński Horacio Cerutti Guldberg (2011). Na gruncie muzyki ideę tę wykorzystała m.in. grupa Los Prisioneros. W 1987 r. nagrała ona piosenkę pt. We are Sudamerican rockers, która została wyemitowana w pierwszym odcinku programu MTV Latin America w dniu 1 października 1993 r. 
lami śpiewu. Często też rodzimym pieśniom ludowym nadawano treści chrześcijańskie. Powstawały nawet opery religijne w lokalnych językach, np. Święty Franciszek Ksawery w języku Indian Chiquito (Gawrycki 2009).

\section{Wykorzystanie folkloru w praktykach ideologicznych}

Korzystanie z zasobów muzyki ludowej przez środowiska spoza wsi przynosi odmienne efekty w poszczególnych krajach. Lokalne uwarunkowania historyczne i polityczne powodują, że do budowania tożsamości narodowej i budzenia świadomości społecznej folklor wykorzystywany jest na różne, czasem wręcz przeciwstawne sposoby, nie tylko przez lewicowe, ale i skrajnie prawicowe ugrupowania polityczne. Dlatego niektórzy badacze twierdzą wręcz, że „w żadnym kraju świata nie pojawiło się zjawisko muzyki zaangażowanej bez bezpośredniego związku z muzyką ludową" (Wyszogrodzki 2005: 87).

Jak wynika z poprzednich rozważań, muzykę nueva canción kształtowały trzy nurty ideologiczne: poszukiwanie odrębnych tożsamości narodowych obok tożsamości „naszoamerykańskiej”, rewitalizacja kultur indiańskich oraz ideologia lewicowa. Muzycy o poglądach lewicowych komponowali niekiedy bezpośrednio na potrzeby lokalnych partii (na przykład na Kubie czy w Chile za rządów Unidad Popular i Salvadora Allende), czyniąc ze swych pieśni część strategii politycznej. Miało to miejsce choćby w przypadku utworu Canto al Programa zespołu Inti-Illimani, na który składały się takie części jak Walc edukacji dla wszystkich czy Pieśń o reformie rolnej. Dokonywano również selekcji gatunków w obrębie muzyki ludowej pod kątem ich przydatności ideologicznej. W ten sposób w chilijskim ruchu nueva canción wyeliminowano utwory typu tonada, w bukoliczny sposób opiewające uroki życia na wsi w bogatych latyfundiach. Niezwykle rozwinął się za to ludowy styl cueca. Argentyński ruch nuevo cancionero również weryfikował wykorzystywany przez siebie folklor pod kątem jego użyteczności politycznej. Jak pisze Pablo Vila (2019: 14-15), „członkowie [tego ruchu] wyraźnie chcieli zmienić muzykę ludową tak, aby towarzyszyła życiu i zmaganiom ludzi, akcentując $\mathrm{w}$ ten sposób bardziej przyszłość niż przeszłość”.

W przypadku latynoamerykańskich ruchów muzycznych z lat 60. i 70. XX w. mieliśmy zatem do czynienia z fuzją muzyki tradycyjnej i słów o wymowie politycznej. Ogólne założenia takiej twórczości wyraził założyciel grupy Quilapayun, Eduardo Carrasco, który pisał: „[c]hcemy [...] tworzyć ekspresyjną muzykę bez ozdób i przesady [...], szukać naszych korzeni [...] i tworzyć muzykę rewolucyjną” (Carrasco 2003: 11) . Za pierwszą pieśń tego ruchu uznaje się utwór La Carta, z melodią ludową oraz tekstem Violety Parry opisującym aresztowanie jej brata w ramach represji za poparcie strajków robotniczych. Wzorcowym utworem tego typu była też Funeral Song for Che Guevara, z tradycyjną muzyką ludową opracowaną przez Parrę i słowami Pablo Nerudy, słynnego chilijskiego poety, laureata Nagrody Nobla i komunisty.

Wyrazem zaangażowania w kulturę Indian stawało się dążenie do uzyskania specyficznego brzmienia poprzez zastosowanie andyjskiego instrumentarium ludowego, w postaci m.in. quena, charango czy bębnów. Kierunek ten wyznaczył argentyński muzyk o pseudonimie Atahualpa Yupanqui, który korzystał z folkloru andyjskiego już na przełomie lat 30. i 40. XX w. Komponował on utwory z wykorzystaniem „stylu andyjskiego” i tekstów piosenek ludowych, głównie Indian Kolla i Calchaqui. 
Choć muzycy nueva canción, a także badacze tego nurtu uznawali go za prekursora gatunku, Atahualpa Yupanqui podkreślał odrębność swoich motywacji. Twierdził, że kierowała nim troska o najbardziej zmarginalizowaną grupę społeczną, jaką byli Indianie, o których w latach 40. XX w. nie wspominał jeszcze program społeczny wprowadzany przez ówczesnego prezydenta Argentyny Juana Perona. Pieśni wzorowane na twórczości ludowej miały więc stać się swoistym narzędziem walki - metaforycznymi grotami indiańskich strzał (Molinero, Vila 2014: 167). Atahualpa Yupanqui eksponował znaczenie kultury Indian, uznawał ją obok kultury kolonizatorów za pełnowartościowe dziedzictwo Argentyny oraz podkreślał równość obu tradycji i ich naturalne następstwo. Tym sam dokonał on przełomu w myśleniu o kulturze swego kraju: dotychczasowi barbarzyńcy, z którymi należało bezwzględnie walczyć, stawali się mądrymi przodkami.

Sprzeciw Atahualpy Yupanqui wobec zaliczania go do grona muzyków nueva canción wynikał z dwóch założeń. Pierwszym było to, że reprezentant ludu nie powinien być zaangażowany w żaden ruch polityczny i musi pozostać niezależny. Pełną niezależność dawała zaś anonimowość twórcy charakterystyczna dla kultury ludowej, której muzyk chciał być wierny. Anonimowość pieśniarza jest zarazem warunkiem zachowania utworu w obszarze kulturze ludowej (Molinero, Vila 2014: 185). Atahualpa Yupanqui uważał wręcz, że muzyka walcząca wypacza istotę muzyki ludowej, która powinna pełnić wyłącznie funkcję zaświadczającą: nie agitować lecz pobudzać i „łaskotać”, wyprowadzać z równowagi bogaczy, a przede wszystkim opowiadać o dramatach ludzkiej egzystencji (Molinero, Vila 2014: 189).

Warto podkreślić, iż częste inspiracje kulturą Indian wiązały się również z faktem, że położenie geograficzne Andów - pasma ciągnącego się przez cały kontynent pozwalało wielu krajom na uznanie andyjskiego folkloru za swój własny, co wzmacniało też poczucie „naszoamerykańskości”. Brzmienie charakterystyczne dla muzyki andyjskiej stało się więc kanonem nueva canción i było tak jednoznacznie kojarzone z pieśnią zaangażowaną, że po puczu wojskowym Pinocheta gra na instrumentach andyjskich została zakazana. Zakaz ten starano się omijać, grając na nich inną muzykę, w tym muzykę poważną, co miało miejsce w przypadku grupy Andean Barogue czy nowego nurtu zwanego canto nuevo, w którym zrezygnowano z tekstów politycznych, jednak zachowano sposób przetwarzania muzyki ludowej nawiązujący do nueva canción. Jak wspominają słuchacze canto nuevo, samo użycie tego zestawu instrumentów rodziło uczucie słuchania muzyki zakazanej (Morris 2014: 34).

Odzwierciedleniem ideologii „naszoamerykańskości” był repertuar chilijskiego zespołu Inti-Illima, który nie dość że odwoływał się do folkloru miejskiego (wówczas jeszcze nie uznawanego za folklor ludowy przez „ortodoksyjnych” badaczy) jako najlepiej odzwierciedlającego sytuacje proletariatu, to jeszcze wykorzystywał nie tylko muzykę chilijską, ale też boliwijską, peruwiańską czy argentyńską. Inny rodzaj praktykowania tej idei znajdziemy w przełomowej kompozycji grupy Quilapayun Cantata popular Santa Maria de Iquique, której poświęcę kolejny fragment artykułu. W tym miejscu zaznaczę tylko, że Cantata jest utworem zarówno wieloetnicznym, jak i w pewnym sensie diachronicznym, to znaczy łączącym w całość różne tradycje etniczne i historyczne. W kontekście wymienionych powyżej praktyk i technik stosowanych do społeczno-politycznej adaptacji muzyki ludowej, kreacyjna funkcja folkloru uwidacznia się bodaj najpełniej. 


\section{Cantata popular Santa Maria de Iquique}

Utwór ten powstał w 1969 r. Zarówno muzyka - będąca kompilacją różnych wątków ludowych i historycznych oraz oryginalnych pomysłów artystycznych - jak i tekst są dziełem Luisa Advisa, który posiadał wykształcenie akademickie. Pierwotnie utwór przeznaczony był dla orkiestry symfonicznej, ostatecznie jednak w $1970 \mathrm{r}$. wszedł do repertuaru wspominanej wcześniej sztandarowej chilijskiej grupy nueva canción - Quilapayun. Treścią Cantaty są wydarzenia z 1907 r., gdy w miejscowości Iquique siły rządowe dokonały masakry protestujących górników z kopalni saletry potasowej oraz ich rodzin. Wydarzenie to było niemal nieobecne w oficjalnej historiografii Chile ${ }^{8}$. Nawiązującą do peruwiańskiego baroku misyjnego formę kantaty wypełniono treściami społeczno-politycznymi; recytatywy zastąpiono narracją o faktach historycznych oraz wezwaniami do solidarności i tworzenia wspólnoty. Zachowano jednak charakterystyczną dla tego gatunku zasadę następstwa różnorodnych form wyrazu artystycznego i podziałów metrycznych tła instrumentalnego9. W niektórych częściach utworu pojawiają się cytaty z ludowych piosenek chilijskich i rytmy indiańskie. Całość grana jest na instrumentach andyjskich, takich jak zampona (fletnia Pana), lutnia charango ${ }^{10}$, bębny czy quena (rodzaj fletów prostych), których brzmienie uzupełniają wiolonczela i kontrabas. Utwór wykonywany był zawsze w specjalnej oprawie scenicznej wypracowanej przez Victora Jarę, ówczesnego lidera Quilapayun. Za bardzo ważny element ideologiczny uznano użycie w tytule kantaty słowa popular, które w języku hiszpańskim odpowiada pojęciu „ludowy” na gruncie języka polskiego.

Mimo początkowego sprzeciwu wobec nowatorskiej formy utworu - wyrażanego przez innych muzyków obecnych na jego premierze podczas II Festiwalu Chilijskiej Nueva Canción w 1970 r. - ostatecznie został on uznany za przełomowy dla tego nurtu i zapoczątkował erę komponowania podobnych dzieł w całej Ameryce Łacińskiej. Wydaje się, że stało się tak dlatego, iż zawarta w warstwie dźwiękowej otwartość stylistyczna i interpretacyjna wobec muzyki ludowej, klasycznej i religijnej (chrześcijańskiej) współgrała z poszukiwaniami źródeł tożsamości nie tylko Chilijczyków, ale też innych zamieszkujących ten kontynent narodów. Otwartość ta stanowiła zarazem swego rodzaju odpowiedź na tożsamościowe dylematy. W różnorodności elementów składających się na ten utwór dochodziło bowiem do manifestacji opisanych wyżej nurtów ideologicznych; można tam znaleźć zarówno idee lewicowe, jak i pomysł rewitalizacji kultur rodzimych mieszkańców Ameryki, a także koncepcje poszukiwania korzeni oraz kultury „naszoamerykańskiej”, której częścią jest również dziedzictwo chrystianizacji kontynentu.

Jak wskazywali muzycy Quilapayun, zawarta w utworze ideologia lewicowa polegała na głoszeniu „duchowej siły zjednoczenia społecznego” (Bolton 2014: 53). Ricardo Venegas Carhart ujął to w następujący sposób:

8 Warto dodać, że w nurcie nueva cancion wydarzenie to zostało podjęte już wcześniej, w piosence zespołu Quilapayun z 1968 r. pt. Canto a la Pampa, która powstała na bazie poezji Carlosa Peoza Veliza (1879-1908), chilijskiego poety, pedagoga i dziennikarza.

9 Struktura muzyczna kantat omówiona jest m.in. w pracach Bohdana Pocieja (1984), Danuty Wójcik (1996) oraz Józefa Chomińskiego i Krystyny Wilkowskiej-Chomińskiej (1984).

10 Charango powstało dopiero po konkwiście, na bazie hiszpańskiej gitary i lutni. Jest to, rodzaj niewielkiej mandoliny, uważany za narodowy instrument Peru. 
Myślę, że wychodzą z koncertu z tym samym uczuciem, z tym obrazem, z tym impulsem, energią mówienia: „Ok. musimy się zjednoczyć. Zjednoczyliśmy się, żeby to nie zdarzyło w Chile nigdy więcej” (Bolton 2014: 53).

Cantata miała zarazem wymiar profetyczny. Jej słowa przestrzegały: „może jutro albo pojutrze, a może później, historia, którą słyszysz, może się powtórzyć” (Bolton 2014: 54). W istocie proroctwo to spełniło się w postaci puczu wojskowego Pinocheta, który nastąpił zaledwie trzy lata po premierze utworu. Mimo panującego wtedy terroru oraz zakazu Cantata została wykonana w 1975 r. w mieście Conception przez tamtejszych więźniów, obrazując ich tragiczną sytuację. Fakt ten przyczynił się do mityzacji tego dzieła muzycznego, które w okresie emigracji Quilapayun było przez nich grane na całym świecie około 40o razy (Bolton 2014: 69) jako wyraz oporu i nadziei na wyzwolenie narodu chilijskiego, a w samym Chile odbierano je jako utwór reprezentujący kulturę narodową (Bolton 2014: 47). O jego narodowej randze świadczą liczne wykonania w różnych stylach (np. w aranżacji rockowej nagranej przez Colectivo Cantata Rock w 2007 r.) (Bolton 2014: 56-64) i ważnych momentach społecznych (np. w czasie strajków studenckich przed Uniwersytetem w Santiago w 2011 r.).

\section{Funkcja zaświadczająca muzyki ludowej}

Pojęcie funkcji zaświadczającej pojawia się w literaturze dotyczącej muzyki u wspominanych wcześniej Pablo Vila (2014) i Carlosa Molinero (2011: 54). Jednak u obu tych autorów nie znajdujemy jego definicji. Używane jest ono raczej intuicyjnie, zgodnie z powszechną praktyka językową. Odwołując się do semantyki oraz etymologii słowa „Zaświadczać” na potrzeby dalszych analiz przyjmuję więc, że funkcja zaświadczająca polega na poświadczaniu prawdziwości opisywanych w pieśniach zjawisk czy wydarzeń, a jednocześnie składaniu swego rodzaju hołdu ich bohaterom.

Dobrym przykładem ujawniania się zaświadczającej funkcji przekazów muzycznych jest repertuar średniowiecznych pieśniarzy, zwłaszcza celtyckich bardów oraz twórczość typu sirventes w wykonaniu francuskich trubadurów z Bertranem de Born na czele ${ }^{12}$. W tego typu utworach przenoszona była pamięć wielkich wydarzeń, często o charakterze politycznym: koronacji, traktatów królewskich czy bitew. Mamy tu do czynienia ze swego rodzaju dokumentacją historyczną charakterystyczną dla kultury oralnej. Funkcja zaświadczająca realizuje się jednak nie tylko w repertuarze historycznym. Jest obecna także w powstającej na bazie folkloru pieśni zaangażowanej, w której uwieczniane są wydarzenia dramatyczne, posiadające zarazem wymiar uniwersalny, będące obrazem ludzkiego losu. Jednym z pierwszych

11 W języku polskim podstawowe znaczenia to: „oficjalnie coś potwierdzić”, „dać dowód czegoś” lub "stać się świadectwem czegoś”. Z kolei w języku angielskim testify wywodzi się z łacińskiego testimonium (dowód, świadectwo) i wiąże się m.in. z podkreślaniem czyichś zasług oraz zabiegami marketingowych budującymi zaufanie i prestiż marki. W polu konotacyjnym czasownika „zaświadczać” prócz potwierdzania i zeznawania pojawiają się więc takie znaczenia jak uznanie, hołd, dowód czy wdzięczność.

12 Sirventes miały często charakter satyryczny, w kontekście tematu niniejszego artykułu ważne jest jednak, że ich cechą było wykorzystywanie starych melodii do nowych treści - zabieg stosowany również w nurcie nueva canción. 
przykładów tego rodzaju pieśni może być utwór Atahualpy Yupanqui zatytułowany El Arriero, który uważa się za prekursorski dla aktywistycznego nurtu nueva canción. Nawiązuje on do kultury gauchos, w owych czasach uchodzącej za rezerwuar „prawdziwego” folkloru Argentyny, dlatego też włączenie do refrenu tej piosenki fragmentu indiańskiej poezji w formie skargi ${ }^{13}$ odebrane zostało jako moment przełomowy w kulturze Ameryki Łacińskiej. Z perspektywy historii muzyki zabieg ten jawi się również jako moment narodzin pieśni zaangażowanej.

$\mathrm{Na}$ funkcję zaświadczającą muzyki wskazuje także Greil Marcus (2011) w kontekście północnoamerykańskiego ruchu folk revival, który rozpoczął się w latach 40. $\mathrm{XX}$ w., a swoje apogeum osiągnął w połowie lat 6o. Historia tego ruchu oraz jego relacja w stosunku do folkloru zasługują na odrębny opis ${ }^{14}$, w tym miejscu skupię się więc jedynie na istotnej dla obu tradycji muzycznych funkcji zaświadczającej, obecnej również w amerykańskim folku, z którego wywodzą się pieśni protestu.

Momentem inicjującym odnowę zainteresowania amerykańską muzyką tradycyjną było nagranie w 1958 r. przez kalifornijski zespół Kingston Trio albumu z balladą pt. Tom Dooley. Utwór ten powstał w 1866 r. na terenie ubogiego regionu Appalachów i opowiadał o tym, jak tytułowy bohater został oskarżony i osądzony za morderstwo, którego prawdopodobnie nie popełnił. Jest to więc piosenka o tematyce sensacyjnej, która jednak zawiera pytania natury ogólnej o losy ludzi uwikłanych w problemy egzystencjalne, o poszukiwanie sprawiedliwości, o fatum wiszące nad postaciami tego dramatu, i w ten sposób realizuje również funkcję zaświadczającą. Dla rodzącego się wówczas w USA ruchu walki o prawa obywatelskie stała się ona źródłem inspiracji, a zarazem charakterystycznego przekonania, które Greil Marcus ujął w następujący sposób: „Biedni są sztuką, ponieważ wyśpiewują swoje życie bez rozmyślania i bez namysłu, bez fałszywej ugody z kapitalizmem i fałszywych pragnień reklamy. [...] A więc [w tym przypadku] to nie śpiewak śpiewa pieśń, lecz pieśń wyśpiewuje śpiewaka” (Marcus 2011: 27). Ówcześni aktywiści z Ameryki Północnej, podobnie jak pieśniarze ruchu nueva canción, sięgali do poświadczanych w muzyce ludowej problemów i wydarzeń oraz szukali w niej prawd ponadczasowych. W latach 6o. XX w. muzyka ta była traktowana jako wyraz protestu wobec nierówności społecznych, biedy i odejścia od ideałów amerykańskiej demokracji. Dzięki swemu uniwersalizmowi mogła też wyrażać obawy przed ówczesnymi zagrożeniami: wojną, konsumpcjonizmem i konformizmem (Marcus 2011: 93). Wskazywała zarazem pewien kierunek poszukiwania rozwiązań aktualnych problemów, a także alternatywny zespół wartości. Robert Shelton, „odkrywca” Boba Dylana,

13 Chodzi o tekst, którego fragment posłużył jako tytułowy cytat do niniejszego artykułu: „Smutki i bydło idą tą samą drogą / Smutek jest nasz, bydło jest ich” (Molinero, Vila 2014: 171).

14 Warto jednak wskazać na pewien istotny aspekt tej relacji. Z jednej strony folk określa się jako rodzaj muzyki popularnej, czerpiącej inspiracje z folkloru (utwory artystyczne intencjonalnie pochodne folklorowi), tworzonej przez osoby spoza środowiska artystów ludowych (Stęszewski 20oo: 9). Z drugiej strony, jak powiada Bob Dylan, utworem tradycyjnym nie musi być historyczna muzyka ludowa. Może nim być również utwór współczesny, z którym jednak wszyscy się identyfikują, przez co - podobnie jak folklor - staje się on dobrem wspólnym (Marcus 2011: 28), choć sama forma łączy go z folkiem. W perspektywie amerykańskiej opozycja folklor-folk ulega więc pewnemu zatarciu, a muzykę folkową ujmuje się często też jako ustnie przekazywaną muzykę jakiejś społeczności, której przypisuje się dodatkowo cechę autentyczności oraz charakter antykomercyjny. Na tej też podstawie amerykański ruch folk revival wykorzystuje tradycyjny folklor muzyczny jako bazę do tworzenia muzyki kontestującej. 
gwiazdy amerykańskiego folk revival, ujął wpływ muzyki tradycyjnej na społeczeństwo amerykańskie lat 6o. XX w. następującymi słowami: „Jest jeszcze jedna droga wyjścia z dylematu współczesnego społeczeństwa miejskiego, która nauczy nas wszystkiego o tym, kim jesteśmy. Na wsi blisko ziemi mieszkają piękni, prości, stosunkowo nieskomplikowani ludzie, którzy mają własną tożsamość, własne pochodzenie. Wiedzą, kim są i wiedzą, jaka jest ich kultura, ponieważ sami ją tworzą" (Marcus 2011: 20).

Głęboka identyfikacja środowiska amerykańskich aktywistów społecznych z przekazem zawartym w muzyce ludowej miała wpływ również na to, że tradycyjna pieśń gospel We shall overcome ${ }^{15}$ wykonana w 1963 r. na festiwalu folkowym w Newport stała się hymnem ruchu praw obywatelskich. Trzeba bowiem zauważyć, że w tamtych czasach powszechną praktyką aktywistów na rzecz praw obywatelskich w Ameryce Północnej było również wykonywanie pieśni religijnych w nowym kontekście, niekiedy ze zmienionymi słowami dostosowanymi do aktualnej sytuacji. Howard Zinn, charakteryzując działania ruchu antydyskryminacyjnego w USA, wspomina, że ich stałym elementem była adaptacja hymnów chrześcijańskich do bieżących potrzeb (Zinn 2016: 584). Sytuację taką opisuje Stokely Carmichael, jeden z działaczy owego ruchu: „[...] szeryf zaczął wyciągać kajdanki. Nie ruszyłem się z miejsca i zacząłem śpiewać: I'm Gonna Tell God How You Treat Me. I wszyscy podchwycili pieśń [...]” (Zinn 2006:588). Użycie pieśni religijnych w takich okolicznościach miało podkreślać uniwersalny wydźwięk spraw, o które walczono, oraz podnieść ich rangę.

Funkcja zaświadczająca wyraźnie zaznacza się również w omawianej wcześniej Cantata popular Santa Maria de Iquique. Jak bowiem stwierdziła Eleen Karmy Bolton, „[n]ajbardziej transcendentalną cechą Cantaty jest jej zdolność do pozostawania aktualną pomimo upływu czasu oraz do ponownego wyrażania i wyjaśniania różnych problemów i wydarzeń w naszej historii poprzez różne muzyczne języki, a jednocześnie do przekazywania tej samej centralnej idei, którą miał na myśli Luis Advis w 1970 roku” (Bolton 2014: 65). Przypadek ten dobrze pokazuje, że funkcja zaświadczająca polega na łączeniu przeszłości z teraźniejszością, a zarazem ostrzeganiu przed przyszłością, czemu służy forma palimpsestu, w którym kolejne warstwy znaczeniowe zachodzą na siebie, jednak nie zakrywają poprzedniej. W Cantatcie mamy więc do czynienia nie tylko $\mathrm{z}$ rewitalizacją i bezpośrednim wykorzystaniem muzyki ludowej, lecz również z zastosowaniem jej funkcji zaświadczającej w muzyce innego typu.

\section{Podsumowanie}

Dokonana w tym artykule analiza twórczości muzycznej powstającej w nurcie nueva canción wskazuje na obecność w niej funkcji zaświadczającej, która występuje też w muzyce ludowej różnych epok i różnych obszarów geograficznych. Funkcja ta - obok funkcji kreacyjnej - jest jedną z najczęściej wykorzystywanych do celów społeczno-politycznych, przy czym odgrywa ona podstawową rolę w muzyce zaangażowanej, takiej jak nueva canción czy amerykański folk, która czerpie inspiracje

15 Utwór Charlesa Alberta Tindleya z 1901 r. 
z muzyki tradycyjnej. Można nawet wzmocnić to spostrzeżenie uznając, że to właśnie funkcja zaświadczająca stanowi swoistą oś, wokół której rozwijają się różne formy muzyki zaangażowanej i walczącej czy pieśni protestu. Fakt iż są one łączone z twórczością ludową sprawia, że rodzą się dzieła o ogromnym potencjale emocjonalnym, co czyni $\mathrm{z}$ nich często utwory zapisujące się $\mathrm{w}$ dziejach narodów jako ich kulturowe dziedzictwo, a poprzez odwołanie do ogólnie zrozumiałych treści również dziedzictwo uniwersalne, wymykające się ze swoich ram narodowych i politycznych. To dowód ich wyjątkowej wartości.

\section{BIBLIOGRAFIA}

Anderson, B. (1997). Wspólnoty wyobrażone: Rozważania o źródłach i rozprzestrzenianiu się nacjonalizmu (przeł. S. Amsterdamski). Kraków: Znak.

Berger, P., Luckman, T. (1983). Społeczne tworzenie rzeczywistości (przeł. J. Niżnik). Warszawa: Państwowy Instytut Wydawniczy.

Bolton, E. K. (2014). „Remembrance is not enough”. The Cantata Popular Santa Maria de Iquique forty years after its release. In: P. Vila (ed.), The militant song movement in Latin America (pp. 45-70). Lanham: Lexington Books.

Carrasco, E. (2003). Quilapayun: La revolución y las estrellas. Santiago de Chile: RIL editors.

Chomiński, J. M., Wilkowska-Chomińska, K. (1984). Wielkie formy wokalne. Kraków: Polskie Wydawnictwo Muzyczne.

Gahr, D., Shelton, R. (1968). The face of folk music. New Jork: The Citadel Press.

Gawrycki, M. (red.) (2009). Dzieje kultury latynoamerykańskiej. Warszawa: PWN.

Gonzales, L. J. (2014). The Chilean New Song's cueca larga. In: P. Vila (ed.), The militant song movement in Latin America (pp. 71-96). Lanham: Lexington Books.

Gramsci, A. (1961). Uwagi o folklorze (przeł. B. Sieroszewska). W: Pisma wybrane. T. 2. Warszawa: Książka i Wiedza.

Guldberg, C. H. (2011). Filozofia naszoamerykańska. Filosofía nuestroamericana (przeł. J. Wojcieszak). Warszawa: Centrum Studiów Latynoamerykańskich UW.

Gwizdalanka, D. (1999). Muzyka i polityka. Kraków: Polskie Wydawnictwo Muzyczne.

Halili, R. (2012). Naród i jego pieśni. Rzecz o oralności, piśmienności i epice ludowej wśród Albańczyków i Serbów. Warszawa: Wydawnictwo Uniwersytetu Warszawskiego.

Laskowska-Otwinowska, J. (2019). Zdobycze komunizmu. O rewolucyjnych pieśniarzach Ameryki Łacińskiej. Etnografia Nowa, 9, 510-540.

Łepkowski, T. (1987). Indianie a naród meksykański: Rewolucyjny indygenizm Cardenasa i Lombardo Toledana. W: M. Paradowska (red.), Trzeci Świat w polskich badaniach etnograficznych (s. 91-109). Warszawa: Muzeum Etnograficzne.

Marcus, G. (2011). The Old, Weird America: The World of Bob Dylan's Basemen. New York: Picador.

Massaka, I. (2003). Polityczna funkcja muzyki. Antyteza estetyki autonomii dzieła muzycznego. Środkowoeuropejskie Studia Polityczne, 1, 75-94.

Massaka, I. (2009). Muzyka jako instrument wpływu politycznego. Łódź: Ibidem.

Merriam, A. (1964). The Anthropology of Music. Evanston: Northwestern University Press.

Molinero, C. (2011). Militancia de la cancion: Politica en el canto folklorico de la Argentina (1944-1975). Buenos Aires: De Aqui a la Vuelta.

Molinero, C., Vila, P. (2014). Atahualpa Yupanqui. The Latin American precursor of the militant song movement. In: P. Vila (ed.), The militant song movement in Latin America (pp. 163 - 191). Lanham: Lexington Books. 
Morris, N. (2014). New Song in Chile: Half a century of musical activism. In: P. Vila (ed.), The militant song movement in Latin America (pp. 19-44). Lanham: Lexington Books.

Pociej, B. (1984). Formy kantatowo oratoryjne. Ruch Muzyczny, 28(25). Pobrano z: http://meakultura. $\mathrm{pl} /$ artykul/formy-kantatowo-oratoryjne-oratorium-1-1084

Reyes, A. (1994). Uwagi o amerykańskiej inteligencji (przeł. J. Wojcieszak). Warszawa: Centrum Studiów Latynoamerykańskich UW.

Smith, A. (1989). The Ethnic Origins of Nations. Oxford: Blackwell.

Stęszewski, J., Żmidziński, J. (200o). Folk przeciw kiczowi. Z Janem Stęszewskim rozmawia Jakub Żmidziński, Czas Kultury, 4, 9-12.

Vila, P. (ed.). (2014). The militant song movement in Latin America. Lanham: Lexington Books.

Weinberg de Magis, L. (1994). Reyesa uwagi o amerykańskiej inteligencji (przeł. J. Wojcieszak). W: A. Reyes, Uwagi o amerykańskiej inteligencji (pp. 19-30). Warszawa: Warszawa: Centrum Studiów Latynoamerykańskich UW.

Wójcik, D. (1999). ABC form muzycznych. Kraków: Musica Iagellonica.

Wyszogrodzki, D. (2005). Folk muzyką ostatnich bardów. W: I. Kiec, M. Traczyk (red.), W teatrze piosenki (s. 87-111). Poznań: Wydawnictwo Poznańskie Studia Polonistyczne.

Zinn, H. (2016). Ludowa historia Stanów Zjednoczonych. Od roku 1492 do dziś (przeł. A. Wojtasik). Warszawa: Wydawnictwo Krytyki Politycznej. 